\title{
The bridging role of regional headquarters. Multinational companies in the Asia-Pacific region
}

\author{
Bruno Amann \\ LGCO, University of Toulouse III, Toulouse, France \\ Jacques Jaussaud \\ CATT, Collège Sciences Sociales et Humanités, University of Pau, e2s-UPPA, Pau, France, and \\ Johannes Schaaper \\ University of Bordeaux, Bordeaux, France
}

\begin{abstract}
Purpose - Large multinational companies (MNCs) are strongly formalized, often standardized and complex with multiple hierarchical levels. Over the past few decades, MNCs have strengthened their coordination and control systems by creating regional headquarters (RHQs). This study aims to investigate how MNCs rearticulate control dimensions at RHQs, to coordinate and exert control over subsidiaries in the Asia-Pacific region.

Design/methodology/approach - Based on a survey of 86 French MNCs in the Asia-Pacific region, this study applies a structural equation model to determine RHQs' roles in the field of regional decision-making, coordination and control.

Findings - Large MNCs, with a significant presence in Asia, transfer coordination and control to RHQs, in a way that leads us to propose the use of the expression "regio-centralization." RHQs become socialization hubs, where most regional decisions are taken and where international managers meet. MNCs mobilize at the same time expatriates, short-term assignees and local managers who intensively interact at RHQs. Thus, informal control at RHQs increases, partly substituting formal control by HQs. Smaller MNCs, without RHQs, on the contrary, base their control and coordination on the formalization of HQs-subsidiary relations, especially through strong reporting, in combination with centralized decision-making at HQs.
\end{abstract}

Research limitations/implications - This study is based on MNCs from one specific country, France, and focuses only on the dynamic Asia-Pacific host region. Coordination and control in less dynamic regions may reveal different results.

Originality/value - This study leads to a better understanding of how large MNCs reorganize dispersed activities in the Asia-Pacific region by creating RHQs, where important control and coordination functions are relocated.

Keywords Centralization-formalization-socialization, Control, Multinational companies, Regional headquarters, AsiaPacific region

Paper type Research paper

\section{Introduction}

Multinational companies (MNCs) have more and more subsidiaries in countries around the world that they must coordinate and control. Large organizations tend to be formalized, standardized and complex and their structure typically features numerous hierarchical levels. In turn, as emphasized by Bartlett and Ghoshal (1989), they look for flexibility or the locate. In other words, MNCs need to balance efficiency derived from standardization and local adaptation. Thus, coordination and control are critical albeit difficult issues for large MNCs. The creation of regional headquarters (RHQs), in the search for this balance, appears to be a key issue (Alfoldi et al., 2012; Ambos, 2016).

Rugman and Brain (2003), Rugman and Verbeke (2008), as well as Oh and Rugman (2014), underline that MNCs expand in specific regions, and not all around the world because of the difficulties of managing activities globally. Most MNCs concentrate their activities in two main regions, such as Europe and North America or Europe and Asia. Ral-Trebacz et al. (2018) find that intra-regional expansion leads to an increase in firm performance, while interregional expansion leads to a decrease. Verbeke and Asmussen (2016) emphasize that the regional level is the key locus for strategy formation; RHQs are implemented to support that aim. 
In this context, control pertains to the process by which one entity influences, to varying degrees, the behavior and output of another entity through the use of power, authority and a wide range of bureaucratic, cultural and informal mechanisms (Geringer and Hebert, 1989,p. 236). Scholars emphasize the diversity of instruments that MNCs implement to control their subsidiaries abroad (Kumar and Seth, 1998; Geringer and Hebert, 1989; Schaan, 1988). A judicious combination of several mechanisms appears key to successful control, such as the share of capital in a subsidiary, the number of expatriates, the formalization of the organization, training and socialization programs for local staff.

Research on the articulation of control mechanisms has produced a theoretically well- established centralization-formalization-socialization framework of control (Ambos and Schlegelmich, 2010; Nobel and Birkinshaw, 1998; Ghoshal and Nohria, 1989). Centralization refers to hierarchical decision-making processes whereby headquarters (HQs) makes most decisions or on the contrary, provides subsidiaries with a specified degree of autonomy that allows them to make decisions about their own strategies. Formalization pertains to written procedures and manuals that attempt to ensure that orders and routine work are properly performed. Socialization is the development of shared values, corporate culture and informal control at all levels in the MNC. Various mechanisms contribute to each dimension of the framework. For instance, written rules, procedures, job descriptions and reporting contribute to the formalization dimension; staff mobility, training and informal personal relations contribute to the socialization dimension (Amann et al., 2017; Ambos and Schlegelmich, 2010; Nobel and Birkinshaw, 1998; Ghoshal and Nohria, 1989).

During recent decades, MNCs have often strengthened their coordination and control mechanisms by creating RHQs (Nell et al., 2011; Kostova et al., 2016). Yeung et al. (2001) show that Western MNCs frequently set up RHQs in Asia with the aim of staying globally integrated and efficient while also becoming more responsive to local opportunities and threats. Nell et al. (2011, pp. 100-101) emphasize that RHQs "manage economies of scale and scope within the region through means of centralization, formalization and socialization." However, Nell et al. (2017) call for further research for a deeper understanding of the emergence, management and consequences of geographically dispersed HQs.

Noting these trends, the current study considers the following research question: when MNCs set up RHQs, how do control dimensions get rearticulated at RHQs to coordinate and exert control over subsidiaries? Do HQs transfer control and coordination to RHQs, which then serve as a bridge between the Asia-Pacific region and the MNCs' HQs? In other words, how is the classic centralization-formalization-socialization model of control affected by the creation of RHQs? To answer this research question, we propose a set of hypotheses that reflect the findings of the recent literature and the results of qualitative interviews that we held with expatriated managers in the AsiaPacific region (Amann et al., 2014, 2017). We test these hypotheses with a quantitative survey completed by representatives of 86 French MNCs in the Asia-Pacific area between 2015 and 2019. We apply a structural equation model, linking the presence of RHQs to the four main dimensions of coordination and control, which are centralization, formalization, socialization and expatriation.

This research makes the following main contributions. We specify how large MNCs transfer coordination and control to the RHQs level, leading us to propose the expression "regio-centralization." RHQs become international socialization hubs, where most regional decisions are taken and where international managers meet. MNCs mobilize at the same time expatriates, short-term assignees and local managers who intensively interact at these RHQs. Thus, informal control at RHQs increases, partly substituting formal control by HQs. On the contrary, smaller MNCs, without RHQs in the Asia-Pacific region, base their control and coordination on the formalization of the HQs-subsidiary relationships, especially through strong reporting in combination with centralized decision-making at the HQs.

This article is structured as follows. The following section details the theoretical background, underlining why MNCs set up regional management centers and how this affects the organization of control and coordination. On the basis of this literature review, we propose a set of hypotheses. We then outline our empirical methodology, data collection and the structural model estimation, including tests of our hypotheses. The last two sections are devoted to the statistical results and a discussion on their implications.

\section{Theoretical background and hypotheses formulation}

As noted, we investigate how control dimensions might be rearticulated at a regional level when MNCs set up RHQs. The literature review first considers regional structures development and then the centralizationformalization-socialization framework of control, leading to the formulation of a set of four hypotheses. 


\section{Regionalization of multinational companies}

Regionalization of management means that a firm establishes intermediate hierarchical management structures in a geographically distant region, such as Asia, Latin America or the Middle East and North-Africa, to which the corporate HQs transfers management responsibilities. This is in line with Schütte and Selmer (1997, p. 441) early definition of a "regional organization," which consists of transferring authority to RHQs "to solve problems in the region, which cannot be handled by the national units, and otherwise would have to be dealt with and acted upon by HQs."

Regionalization is developing rapidly, especially in dynamic regions such as Asia (Arregle etal., 2016; Ambos and Schlegelmich, 2010). Piekkari et al. (2010, p. 527) state that the:

[... .] persistence of cultural, geographic and language distances, the lack of social integration and strong economic growth strengthened the position of the regional organization [... .] in the turbulent, distant region of Asia-Pacific.

Kostova et al. (2016, p. 180) confirm that "many MNCs had begun developing regional centers of coordination and control to better seize regional opportunities, and leverage local resources and knowledge throughout the entire organization."

Belderbos et al. (2017), acknowledging that "the emergence of RHQs is one of the responses to the regionalization trend in the world economy" (op. cit.: 5), find that most RHQs are located in Europe and the AsiaPacific region, less in North America and nearly none in Latin America or Africa. With regard to the country of origin, Japanese MNCs do not and Asakawa, 1999), whereas Enright (2005) finds that there are very few differences between the responsibilities that American and European firms give to their regional structures in Asia.

There is an academic debate on what exactly regional management centers are and what they do. Mori (2002) ranks regional management centers into RHQs, regional offices, distribution platforms, parts centers, representative offices and holding companies, which is consistent with Enright's (2005) typology (RHQs, regional offices and local offices) or Schütte and Selmer (1997) ranking into RHQs, representative offices, holding companies and regional organizational units.

Throughout the academic discussion, the term "RHQs" appears constantly, with varying definitions, which are closely aligned. Schütte and Selmer (1997) considers RHQs as organizational units focused on the integration and coordination of an MNC's regional activities, such that they constitute the link between the region and the HQs. Yeung et al. (2001, p. 158) define RHQs "as a business establishment that has control and management responsibilities for the operations of subsidiaries located in the same host region." According to Poon and Thompson (2003), RHQs "take control over the operations of other subsidiaries located in other countries of a region, without having to refer too frequently to parent HQs."

What are the specific functions of regional management centers, in general, and RHQs in particular? Research by Chakravarty et al. (2017) on Japanese regional management centers shows that the most frequently observed regional functions are accessing local markets, regional information collection, knowledge seeking, exporting to third countries, as well as establishing distribution and production networks. Arregle et al. (2018) conclude that the 547 Japanese multinationals in their sample "integrate their internationalization decisions across countries at the regional level." Both studies, however, focus on Japanese multinationals, which are known for not widely delegating management responsibilities to regional structures.

Hoenen et al. (2013), with a sample of 40 RHQs located in Europe, find that they may undertake entrepreneurial activities, such as the recognition, identification, evaluation and exploitation of regional opportunities. Belderbos et al. (2017) point out that "RHQ both perform intra-regional coordination and control activities and entrepreneurial opportunity- seeking tasks." The entrepreneurial role comprises "scouting for talent, seeking out new business opportunities, signaling commitment to local markets and sharing information with corporate HQ." The second role, which they call, "administrative" includes "serving as the command, control and coordination center of dispersed activities in the region, orchestrating resource pooling and leading the effort to achieve intrafirm synergy."

Close to this distinction, Alfoldi et al. (2012, pp. 284-285), based on a case study of a large Anglo-Dutch MNC, find evidence that regional management centers in Europe perform "entrepreneurial and/or integrative roles." The entrepreneurial role includes strategic direction provision, human resources recruitment and resource development on a regional level, as well as seeking and exploiting new opportunities. The integrative role "entails a strong element of monitoring and control," local human resource management, knowledge sharing through a series of 
activities, which might be qualified as socialization, including, "phone and email exchanges, benchmark visits, training, workshops [.. .] team-building, expatriation, joint projects, job swaps, coaching." Our research question on how control dimensions are rearticulated at RHQs is more related to what Belderbos et al. (2017) call the administrative role and what Alfoldi et al. (2012) call the integrative role of RHQs.

\section{The centralization-formalization-socialization framework of control}

The centralization-formalization-socialization framework goes back to Ghoshal and Nohria (1989), who argue that optimal HQs-subsidiary relations require a combination of centralized decision-making, formalization and normative integration. Centralization, they explain, refers to hierarchical decision-making, such that HQs make most of the crucial decisions. They regard formalization as routine decision-making and resource allocation, with the help of manuals, standing orders and procedures. Normative integration, leading to shared values, includes periods during which subsidiaries' managers work at HQs, HQ's mentors for subsidiaries' managers, and HQs visits to subsidiaries. Normative integration refers to socialization, a widely used term in organization theory. Nine years later, Nobel and Birkinshaw (1998) confirmed that these three modes of control - centralization, formalization and socialization - had been well-established in organization theory. Ambos and Schlegelmich (2010) also acknowledge that the wide range of control mechanisms implemented by MNCs can be articulated according to the three dimensions that Ghoshal and Nohria (1989)identified.

Harzing and Noorderhaven (2006) also identify three control mechanisms:

(1) Autonomy, which is the opposite of centralization (e.g. design, pricing and advertising of products for local markets).

(2) Socialization and networks (e.g. international task forces, training, informal communication with HQs and shared values).

(3) Formal control (formalization, planning, reporting and enterprise resource planning (ERP)).

Moreover, they consider expatriation (number, nationality and key positions of expatriates) as a stand-alone, complementary control mechanism. In this sense, they extend the centralization-formalization-socialization framework.

Amann et al. (2017) find that, to retain control over their Asian subsidiaries, MNCs articulate four main mechanisms:

(1) Centralization of decision-making at HQs.

(2) Formalization of both the organization of subsidiaries and the relationships between subsidiaries and HQs.

(3) Informal contacts and socialization through frequent short-term missions and visits, facilitated by the establishment of RHQs.

(4) Expatriation.

These results are similar to Harzing and Noorderhaven's (2006) findings, yet they are based on different samples and methodologies.

We adopt in our structural equation model the extended centralization-formalization- socialization-expatriation framework. On the basis of this extended framework, we seek to answer our research question: how are control dimensions rearticulated at RHQs to coordinate and exert control over subsidiaries? Accordingly, we offer a set of four hypotheses, $\mathrm{H} 1$ to $H 4$.

Regarding the centralization dimension of control, RHQs are often created because HQs struggle to manage and control the increasing number of subsidiaries in an increasing number of countries. Therefore, decision-making, not just control, might be transferred at least partly to RHQs, under the specific guidance of HQs. According to the academic literature, strategic decision-making is one of the RHQs functions (Chakravarty et al., 2017). Alfoldi et al. (2012, p. 276) identify that both strategic and operational functions are delegated to RHQs, which provides several benefits for MNCs:

- The ability to balance integration and responsiveness within a region. 
- The exploitation of local operational expertize on a regional level.

- Relieving HQs of the burden of monitoring remote peripheral agents.

Schotter et al. (2017) and Mahnke et al. (2012) emphasize that RHQs add information processing capacities to the MNC at the regional level. Thus, having an RHQs may reduce the need for centralization of decision-making at the HQs level. We thus, formulate our first hypothesis:

H1. Regional structures development by MNCs affects the centralization of decisionmaking.

We break down H1 into two sub-hypotheses, namely:

S-H1a. Regional structures development by MNCs reduces the centralization of decision-making at HQs.

$S-H 1 b$. Regional structures development by MNCs increases the centralization of decision-making at RHQs.

Regarding socialization, RHQs become places where expatriates and staff members from HQs or from the global network of subsidiaries go to on short-term missions, which increases interactions with local staff and favors socialization (Tahvanainen et al., 2005; Mayerhofer et al., 2004). Thus, these authors establish the involvement of HQs in socialization via RHQs; this goes against the intuition that socialization is delegated to the regional level without the involvement of HQs. Nell et al. (2011, p. 100) affirm that "RHQ act as fundamental drivers of socialization mechanisms." Furthermore, as RHQs provide opportunities to interact with and train local managers, and to ensure their loyalty (Wong and Law, 1999), they help in localizing management positions. We thus, formulate our second hypothesis:

H2. Regional structures development by MNCs increases the socialization dimension of control.

With regard to formalization, Nell et al. (2011) found that RHQs strengthens formalization and standardization at the regional level. However, to the best of our knowledge, the academic literature does not assert any clear influence of regional structures development on the control through formalization at the level of the whole MNC. Because RHQs are geographically closer to subsidiaries, with increased direct contact, we might expect fewer formal exchanges between subsidiaries and HQs. Yet, the recent development of worldwide ERP systems managed centrally by HQs, instead might support stronger formalization (Willis and Chiasson, 2007). However, in line with Alfoldi et al. (2012), it should be noted that the development of regional structures leads to the implementation of policies adapted to the regional context, which reduces the degree of formalization at the HQ level. We thus, formulate our third hypothesis:

H3. Regional structures development by MNCs reduces the level of HQs control by formalization.

Appointing expatriates to key management positions in a subsidiary is often required to develop activities abroad, and it is a key instrument of control by HQs over overseas activities (Ando et al., 2008; Edström and Galbraith, 1997; Perlmutter and Heenan, 1974). MNCs rely on expatriates for several reasons. First, key subsidiaries' management positions require substantial interactivity with HQs; the informal networks that expatriates enjoy within the MNC provide a good foundation. Second, managing subsidiaries requires specific knowledge of the MNC's processes; if a subsidiary has been recently created, only expatriates have such knowledge (Schaaper et al., 2013). However, expatriation is costly, and expatriates are sometimes disoriented and underperform in foreign contexts (Tung, 1981). Thus, MNCs also seek to localize management positions, replacing expatriates with locals, as long as they can train them and ensure their loyalty to the firm (Selmer, 2003; Wong and Law, 1999). By setting 
up RHQs, MNCs can reduce the need for expatriates. For instance, an expatriate might serve as chief financial officer at the RHQs level, supported by good local finance managers in each subsidiary (Schaaper et al., 2013). Thus, RHQs facilitate the localization of management positions. Therefore, RHQs offer a way to reduce the need for expatriates in the Asia-Pacific region. We thus, formulate our fourth hypothesis:

H4. Regional structures development by MNCs reduces the need for expatriates.

We tested our hypotheses using partial least squares-based structural equation modeling with a sample of 86 French subsidiaries.

\section{Methodology}

Our hypotheses can be aligned in a structural equations model, as follows:

In Figure 1, the circles are latent variables or constructs, which measure abstract and not directly observable phenomena, requiring the use of indirect variables, called indicating variables or indicators, also frequently called manifest, observable or outer model variables (Hair, 2016, p. 6). The structural equation model has one exogenous latent variable, regional structures development by MNCs, explaining the five subsequent endogeneous latent constructs (Hair, 2016, p. 12).

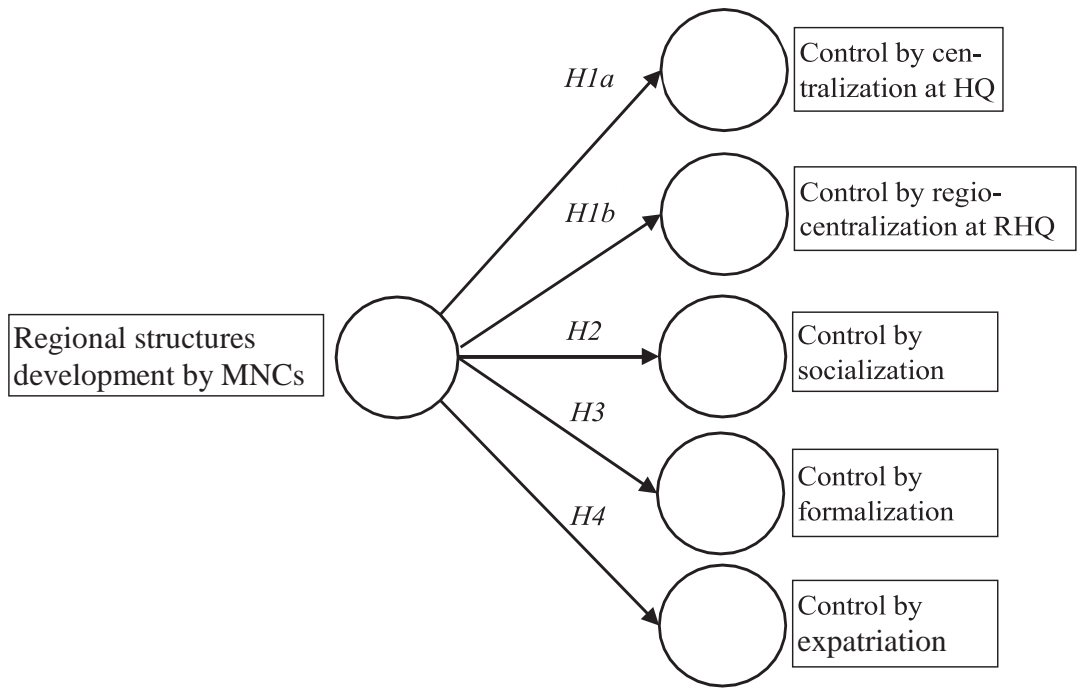

Figure 1. Graphical description of the theoretical structural equations

The type of relationship between latent constructs and their indicating variables can be reflective or formative. Conventional measurement practice is based upon reflective measurement, whereby the direction of causality is assumed to go from the constructs to the indicators. All our latent constructs are reflective. For example, we hypothesize that setting up an RHQs leads to a reinforcement of the socialization dimension of control, through HQs visits and training of local employees (H2).

Our structural model is a first-order model, which tests only one layer of cause-and-effect relationships between latent constructs (Hair, 2016, p. 39). Relationships between latent constructs are called the "structural model" or "inner model" with "path coefficients." The relationships between the latent constructs and their respective indicating variables are called the "measurement model" or "outer model." Each indicating variable is statistically linked to its latent construct by "loadings," in the case of reflective constructs.

A sample of $86 \mathrm{MNCs}$, based in the Asia-Pacific region, allows the quantification of the structural equation model. We opted for the partial least squares-structural equation modeling (PLS-SEM) software 
SmartPLS 3.0, which has several well-known advantages that are particularly useful in our case. In particular, PLS-SEM works efficiently with small sample sizes, does not require underlying data to be normally distributed and can easily handle single-item latent constructs, with no identification problems. Moreover, PLS-SEM can apply to metric, ordinal scaled or binary coded variables. We notice that PLS structural equation modeling is more and more used in international management research.

We carefully followed the six stages of a PLS-SEM approach recommended by Hair (2016):

(1) Specification of the structural model (Figure 1).

(2) Measurement of the structural modelindicators.

(3) Data collection and examination.

(4) Model estimation.

(5) Evaluation of the quality of the outer measurement models.

(6) Evaluation of the quality of the structural model.

\section{Measurement of the structural model indicators}

Table 1 contains the latent constructs, their measurements and the variable names reported on the full structural equation model.

Control by centralization at HQ and Control by regio-centralization at RHQs are single- item latent constructs, measured by only one indicating variable. Diamantopoulos et al. (2012) state that single-item measures should only be used for pragmatic reasons, especially when:

- The sample size is rather small.

- Path coefficients of 0.30 and lower are possible.

- Items of an originating multi-item scale are homogeneous.

- Indicating items of the original questionnaire are semantically redundant.

The other latent constructs are measured by two to four indicating variables, operationalized by one or more questions on the questionnaire. Each question has its own closed-ended answer scale,

\begin{tabular}{|c|c|c|}
\hline Latent construct & Measurement by indicating variables & Variable name \\
\hline $\begin{array}{l}\text { Regional structures } \\
\text { development }\end{array}$ & $\begin{array}{l}\text { Does the MNC have a RHQs in the Asia-Pacific? } \\
\text { Number of functions of the RHQs } \\
\text { Number of regional mamagement centers in the } \\
\text { Asia-Pacific region }\end{array}$ & $\begin{array}{l}\text { RHQ } \\
\text { Functions_RHQ } \\
\text { No_RMCs }\end{array}$ \\
\hline $\begin{array}{l}\text { Control by } \\
\text { centralization at } \mathrm{HQs}\end{array}$ & $\begin{array}{l}\text { Level of centralization of decision-making at } \\
\mathrm{HQs}\end{array}$ & Centr_HQ \\
\hline $\begin{array}{l}\text { Control by } \\
\text { centralization at RHQ }\end{array}$ & $\begin{array}{l}\text { Level of centralization of decision-making at } \\
\text { RHQs }\end{array}$ & Centr_RHQ \\
\hline $\begin{array}{l}\text { Control by } \\
\text { socialization }\end{array}$ & $\begin{array}{l}\text { Level of informal control } \\
\text { Level of training } \\
\text { Number of HQs managers visit s to RHQs anf } \\
\text { subsidiaries and short-term assignments } \\
\text { Level of shared values }\end{array}$ & $\begin{array}{l}\text { Inf_control } \\
\text { Training } \\
\text { Visits_STA } \\
\text { Shared_values }\end{array}$ \\
\hline $\begin{array}{l}\text { Control by } \\
\text { formalization }\end{array}$ & $\begin{array}{l}\text { Level of formal control by HQs } \\
\text { Level of reporting to HQs } \\
\text { Number of written formal documents and } \\
\text { procedures }\end{array}$ & $\begin{array}{l}\text { Formal_control_HQ } \\
\text { Reporting_HQ } \\
\text { Written_formal }\end{array}$ \\
\hline $\begin{array}{l}\text { Control by } \\
\text { expatriation }\end{array}$ & $\begin{array}{l}\text { Number of key functions occupied by } \\
\text { expatriates } \\
\text { Level of localization of management positions } \\
\text { Number of expatriates }\end{array}$ & $\begin{array}{l}\text { Kf_expats } \\
\text { Localization } \\
\text { No_expats }\end{array}$ \\
\hline
\end{tabular}


which might be binary (0/1), Likert scales or quantitative numbers. Some variables are composites, such as the number of functions of RHQs or "level of centralization of decision-making at HQs." [1] To measure opinions and feelings in social sciences, ordinal scales are frequently used. For instance, Harzing and Noorderhaven (2006, p. 172) explain that the "subjective constructs in [their] study were measured with multi-item scales" such as a "three-item scale measuring the level of formalization." The answering scales on our questionnaire are based on the scales used by leading empirical research studies on control and coordination of overseas subsidiaries (Ghoshal and Nohria, 1989; Nohria and Ghoshal, 1994; Nobel and Birkinshaw, 1998; Kim et al., 2003; Harzing and Noorderhaven, 2006; Ambos and Schlegelmich, 2007). Appendix 2 details these answer scales.

\section{Data collection and sample description}

We designed an online survey in French and English, which we programmed at the website of the University of XXX. The target population for filling in our questionnaire are French MNCs with subsidiaries in the Asia Pacific region. It is difficult to assess the exact size of this target population. However, the French Ministry of Foreign Affairs estimate the number of French companies in Asia-Oceania around 8,000, which includes subsidiaries of MNCs.

Thanks to the official paper directories published by the French Chambers of Commerce and Industry in 11 countries in Asia and internet websites listing French companies in eight other Asian countries, most of them also established by The French Chambers of Commerce and Industry and French embassies, we have been able to establish a list of 1,103 expatriated managers, working for French subsidiaries in Asia, with their professional and/ or email addresses.

We carried out the survey between 2015 and 2019. We repeatedly sent requests to fill in our questionnaire to the 1,103 contacts of our list. In total, we received 96 completed questionnaires, of which 86 were fully usable, which is a response rate of $8.7 \%$.

We received answers from respondents working in 18 Asian countries: $34 \%$ were from China, $12 \%$ from Japan, 7\% from Hong Kong, 7\% from Malaysia and the remaining 40\% from 14 other Asian countries, where no single country exceeded $5 \%$ of the final sample. The sample provides diversity in terms of both MNC size and the nature of their activity: for instance, $7 \%$ of the MNCs in our sample are in the natural resources sector (mining and agriculture), 57\% in the manufacturing industry (heavy industry, machinery, industrial pieces, food industry, paper and transport...), 26\% in the services sector, including banking, transport and communications and $7 \%$ are in the energy sector (oil, gas and electricity).

Table 2 contains the main characteristics of the 86 MNCs in our sample.

According to Hair (2016, p. 20), the minimum sample size for PLS-SEM should be the greater of 10 times the largest number of indicators used to measure a single construct $(n=50$ in our case) and 10 times the number of independent constructs in the structural model $(n=40$ in our case). With a final sample size of 86 observations, our research meets this "10 times" rule. However, we have to admit that because of the difficulties in getting MNCs to respond to the survey, the sample size is not large enough for confirmatory statistical modeling. For this reason, we consider our research to be exploratory.

\section{Model estimation}

We initially estimated the full model with 15 indicating variables and 6 latent constructs with SmartPLS 3.0[2]. Three indicating variables did not reveal significant loadings and were omitted from the SEM[3]. The final model was estimated with the remaining 12 indicating variables.

Figure 2 reproduces this structural equation model, estimated with structural path coefficients and the levels of significance[4].

\section{Quality of the outer measurement and structural equation models}

To assess the quality of the six reflective measurement constructs, we used Cronbach's a, the composite reliability (CR) and the average variance extracted (AVE) measures (Hair, 2016). Table 3 provides the main statistics of the outer model.

For measuring the internal consistency reliability, Hair (2016, p. 101) states that the CR measure is more appropriate than Cronbach's a. They add that in advanced research studies, CR values between 0.70 and 0.90 are satisfactory, which is the case in our modeling. To assess the convergent validity of constructs, the AVEs must be 
superior to 0.5 , which is the case of the constructs of our modeling. The coefficients of determination (R2) for the latent constructs, measuring the model's predictive accuracy, reveal values ranging from

Table 2 .

\section{dathecharacteristics}

companies in our sample

\begin{tabular}{llll}
\hline Variable & Small MNCs & \multicolumn{2}{l}{ Medium-sized MNCs Large MNCs } \\
\hline Number in the sample & 33 & 25 & 28 \\
Percentage of the sample & $38 \%$ & $29 \%$ & $33 \%$ \\
Worldwide sales & $<\mathrm{e} 1 \mathrm{bn}$ & Mean $=\mathrm{e} 4 \mathrm{bn}$ & $\mathrm{e} 5 \mathrm{bn}-\mathrm{e} 35 \mathrm{bn}$ \\
Employees worldwide & $<5,000$ & Mean $=10,000$ & $10,000-150,000$ \\
Number of countries worldwide & $<20$ & 20 to 50 & $>50$ \\
Number of subsidiaries worldwide & $<20$ & 20 to 50 & 50 to 500 \\
Sales in the Asia-Pacific region & $<\mathrm{e} 100 \mathrm{~m}$ & Mean $=\mathrm{e} 380 \mathrm{~m}$ & Mean $=\mathrm{e} 5.5 \mathrm{bn}$ \\
Employees in the Asia-Pacific region & $<1,000$ & Mean $=5,000$ & $>5,000$ \\
Countries in the Asia-Pacific region & $<5$ & 5 to 10 & 10 to 30 \\
Subsidiaries in the Asia-Pacific region & $<5$ & $<10$ & 10 to 50 \\
Production activities in the Asia-Pacific region & $50 \%$ of the MNCs & $80 \%$ of the MNCs & $80 \%$ of the MNCs \\
\hline
\end{tabular}

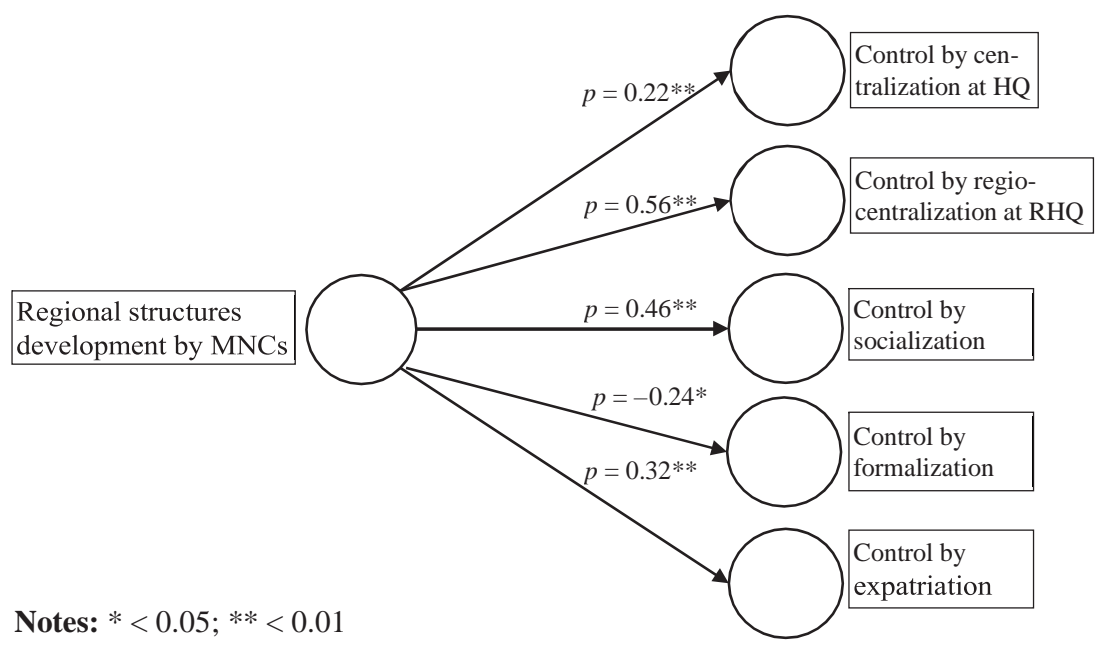

Figure 2. PLS-SEM inner model with path coefficients andlevels of significance

\begin{tabular}{|c|c|c|c|c|c|c|c|c|c|c|}
\hline Construct & Variable name & $\begin{array}{l}\text { Mean } \\
\text { value }\end{array}$ & SD & $\begin{array}{c}\text { Normalized } \\
\text { loadings }\end{array}$ & $P$-value & Cron-bach'sā & $\mathrm{CR}$ & AVE & $R^{2}$ & \\
\hline \multirow{7}{*}{$\begin{array}{l}\text { Regional } \\
\text { structures } \\
\text { development } \\
\text { Centralization } \\
\text { at HQs } \\
\text { Centralization } \\
\text { at RHQs }\end{array}$} & RHQ & 0.67 & 0.47 & 0.89 & 0.00 & & & & & \\
\hline & Functions_RHQ & 3.07 & 2.52 & 0.93 & 0.00 & & & & & \\
\hline & No_RMCs & 1.09 & 1.18 & 0.87 & 0.00 & 0.88 & 0.93 & 0.81 & - & \\
\hline & Centr_HQ & 2.38 & 1.25 & 1.0 & & 1.0 & 1.0 & 1.0 & 0.05 & \\
\hline & Centr_RHQ & 2.46 & 1.19 & 1.0 & & 1.0 & 1.0 & 1.0 & 0.31 & \\
\hline & Inf_control & 3.20 & 1.02 & 0.70 & 0.00 & & & & & \\
\hline & Träining & 3.44 & 0.85 & 0.61 & 0.00 & & & & & \\
\hline \multirow[t]{2}{*}{ Socialization } & Visits_STA & 2.98 & 1.17 & 0.83 & 0.00 & 0.59 & 0.77 & 0.53 & 0.21 & \multirow{4}{*}{$\begin{array}{r}\text { Table } 3 . \\
\text { Final measurement } \\
\text { model and summary } \\
\text { statistics }\end{array}$} \\
\hline & Formal_control_HQ & 3.92 & 1.01 & 0.62 & 0.06 & & & & & \\
\hline Formalization & Reporting_HQ & $\begin{array}{l}3.52 \\
2.56\end{array}$ & $\begin{array}{l}1.18 \\
0.96\end{array}$ & $\begin{array}{l}0.71 \\
0.87\end{array}$ & $\begin{array}{l}0.00 \\
0.00\end{array}$ & 0.46 & 0.71 & 0.54 & 0.07 & \\
\hline Expatriation & No_expats & 14.13 & 23.26 & 0.82 & 0.01 & 0.26 & 0.72 & 0.57 & 0.10 & \\
\hline
\end{tabular}


to 0.42 . As Hair (2016, p. 175) notes, it is difficult to provide rules of thumb for acceptable R2 values because it depends on the model complexity and the research discipline; R2 values of 0.20 are considered high in social science disciplines. The final structural model (Appendix 1) shows the loadings of the indicating variables, which are all above the 0.5 limit[5]. The test for discriminant validity and the cross-loadings of the indicating variables did not reveal any problems. The final structural equation model, retaining only the 12 indicating variables that passed the quality tests, did not reveal any collinearity among the latent constructs[6]. Finally, the path coefficients of the inner structural model are all significant at the 0.05 level.

\section{Results}

Before commenting on our hypotheses, comparative statistics are helpful in better interpreting our structural equation model.

Compared with the $28 \mathrm{MNCs}$ in our sample without an RHQs in the Asia-Pacific region, Table 4 shows that the $58 \mathrm{MNCs}$ in our sample with at least one RHQs in the Asia-Pacific region, are larger on a worldwide scale $(\mathrm{t}=2.64$. sign. $=0.01)$ and have significantly more sales in the region $(\mathrm{t}=1.91$. sign. $=0.06)$. All the other measures, although not statistically significant, show a trend that MNCs with at least one RHQs have more activities in more countries, more subsidiaries, more employees and more production plants in the Asia- Pacific region than MNCs without an RHQs (Table 5).

Compared to the 58 MNCs with RHQs, the 28 MNCs without RHQs in the Asia-Pacific region base their international control system much more on formalized control, especially through strong formal reporting to HQs $(\mathrm{t}=3.2$; sign. = 0.00). On the contrary, the $58 \mathrm{MNCs}$ with at least one RHQs in the Asia-Pacific region centralize more decision-making both at HQs $(\mathrm{t}=2.40$; sign. $<0.02)$ and at RHQs $(\mathrm{t}=3.93$; sign. $<0.00)$, send significantly more visitors and short-term assignees to the region $(\mathrm{t}=3.93$; sign. $<0.00)$, train significantly more their local employees $(\mathrm{t}=2.54$; sign. $<0.01)$ and localize significantly more key management positions $(\mathrm{t}=2.35$; sign. <0.02).

One might fear differences according to industries. analysis of variance and t-test comparing the average latent variables scores for each industry did not reveal any significant difference in the implementation of the control dimension between the manufacturing versus service industry.

Table 6 summarizes the hypotheses and their path coefficient values, which allows us to validate or invalidate our predictions.

The positive and significant value $(\mathrm{p}=0.22$, sign. $=0.04)$ of the structural path coefficient

leading from regional structures development to control by centralization at HQs invalidates $H 1$. The development of RHQs or regional management centers does not reduce the centralization of decision-making at HQs. Large MNCs on a worldwide scale, with important sales in the Asia-Pacific region, set up one or more regional management centers to which they transfer managerial functions. However, while extending their regional management centers, they do not give up a certain level of centralized decision-making.

\begin{tabular}{|c|c|c|c|c|}
\hline Variable & $\begin{array}{c}\text { Mean value of } 28 \mathrm{MNCs} \\
\text { without RHQs in Asia- } \\
\text { Pacific }\end{array}$ & $\begin{array}{c}\text { Mean value of } 58 \mathrm{MNCs} \\
\text { with RHQs in Asia- } \\
\text { Pacific }\end{array}$ & $\begin{array}{l}\text { Mean- } \\
\text { difference }\end{array}$ & $\begin{array}{l}t \text {-value } \\
\text { (sign.) }\end{array}$ \\
\hline $\begin{array}{l}\text { Production in Asia-Pacific region } \\
\text { Number of coum tries in the Asia- }\end{array}$ & $59 \%$ & $72 \%$ & $\begin{array}{l}13 \% \text { - } \\
\text { points }\end{array}$ & $121(0.23)$ \\
\hline $\begin{array}{l}\text { Pacific where the MNC has } \\
\text { activities }\end{array}$ & 7 & 8.3 & 1.3 & $0.83(0.41)$ \\
\hline $\begin{array}{l}\text { Number of subsidiaries in the Asia- } \\
\text { Pacific }\end{array}$ & 5.6 & 10.0 & 4.4 & $1.56(0.12)$ \\
\hline $\begin{array}{l}\text { Number of employees in the Asia- } \\
\text { Pacific ( } \times 1,000 \text { employees) }\end{array}$ & 232 & 2.72 & 0.4 & $1.31(0.19)$ \\
\hline Sales MNC in Asia-Pacific $(\times \mathrm{elm})$ & 214.5 & 513.7 & 299 & $1.91(0.06)$ \\
\hline $\begin{array}{l}\text { Size MNC worldwide (three-point } \\
\text { scale, } 1=\text { small, } 2=\text { medison, } 3= \\
\text { large) }\end{array}$ & 1.6 & 2.1 & 0.5 & $2.64(0.01)$ \\
\hline
\end{tabular}


Table 4. Main characteristics of MNCs with or without RHQs in the Asia-Pacific region (significant differences are italic)

The structural path coefficient leading from regional structures development to control by centralization at RHQs $(p=0.56, \stackrel{\times}{\text { sign. }}<0.00)$ clearly shows that HQs transfer important coordination and control functions to RHQs. Thus, H1b is validated. This combination of transferring important control and coordination functions with decision-making autonomy to RHQs, while maintaining a certain level of central decision-making at HQs leads us to propose the use of the expression "regio-centralization".

The structural path coefficient leading from regional structures development to control by socialization has a value of 0.46 (sign. = 0.00). When MNCs set up RHQs and/or other regional management centers in the Asia-Pacific region, they increase the level of control by socialization, thus validating $\mathrm{H} 2$. The loadings of its indicating variables reveal the primary importance of HQs visits and short-term assignments $(1=0.83$, sign. $=$ 0.00). We see that the indicating variable Informal control $(1=0.70$, sign. $=0.00)$ also strongly contributes to the

\begin{tabular}{lcccc}
\hline $\begin{array}{l}\text { Cocrdination and control mechanism } \\
\text { (indicating variables) }\end{array}$ & $\begin{array}{c}\text { Mean value of 28 } \\
\text { MNCs without RHQs MNCs with RHQs sean value of 58 }\end{array}$ & $\begin{array}{c}\text { Mean } \\
\text { difference }\end{array}$ & $\begin{array}{c}t \text {-value } \\
\text { (sign.) }\end{array}$ \\
\hline $\begin{array}{l}\text { Centralization of decision at HQs } \\
\text { Centralization of decision at RHQs }\end{array}$ & 1.8 & 2.6 & 0.74 & $2.40(0.02)$ \\
Visits and short-term assignments & 1.6 & 2.7 & 1.11 & $3.93(0.00)$ \\
Informal control & 2.3 & 3.3 & 1.02 & $3.93(0.00)$ \\
Level of training in the Asia-Pacific region & 2.9 & 3.3 & 0.46 & $1.90(0.06)$ \\
Formal control by HQs through written & 3.0 & 3.6 & 0.61 & $2.54(0.01)$ \\
formal documents & 4.1 & & & \\
Level reporting & 4.2 & 3.1 & -0.01 & $-0.05(0.96)$ \\
Level of formal control by HQs & 4.1 & 3.3 & -0.91 & $-3.20(0.00)$ \\
Number expatriates in Asia Pacific & 8.7 & 15.7 & -0.25 & $-0.94(0.35)$ \\
Key functions expatriates & 3.1 & 3.1 & -0.09 & $-0.30(0.76)$ \\
Localization of management functions in & & & & \\
the Asia-Pacific region & 2.1 & 2.7 & 0.65 & $2.35(0.02)$ \\
\hline
\end{tabular}

Table 5. Comparison of control and coordination mechanisms transferred to MNCs with and without RHQs (significant differences are italic

\begin{tabular}{|c|c|c|c|c|}
\hline Hypo-thesis & Hypothesized path & $\begin{array}{l}\text { Standardized path } \\
\text { coefficient }\end{array}$ & Significance level & Result \\
\hline$H 1 a$ & $\begin{array}{l}\text { Regional structures development } \\
\text { by MNCs reduces the } \\
\text { centralization of decision-making } \\
\text { at }\end{array}$ & 0.22 & 0.04 & Invalidated \\
\hline$H 1 b$ & $\begin{array}{l}\text { Regional structures development } \\
\text { by MNCs increases the } \\
\text { centralization of decision-making } \\
\text { at RHQs }\end{array}$ & 0.56 & 0.00 & Validated \\
\hline $\mathrm{H} 2$ & $\begin{array}{l}\text { Regional structures development } \\
\text { by MNCs increases control by } \\
\text { socialization }\end{array}$ & 0.46 & 0.00 & Validated \\
\hline$H 3$ & $\begin{array}{l}\text { Regional structures development } \\
\text { by MNCs reduces HQs control by } \\
\text { formalization }\end{array}$ & -0.24 & 0.04 & Validated \\
\hline$H 4$ & Regional structures development & 0.32 & 0.00 & Invalidated \\
\hline
\end{tabular}

socialization dimension of control. RHQs and other regional management centers become socialization hubs, where HQs managers on business visits, short-term assignees, expatriates and other Asia-Pacific managers meet, 
exchange information informally and develop social networks. The indicator Training $(1=0.61$, sign. $=0.00)$ show that RHQs frequently organize training, especially for local managers in the Asia-Pacific region.

As hypothesized, the path relationship from regional structures development to control by formalization shows a significant negative value $(\mathrm{p}=0.24$, sign. $=0.04)$, which validates $\mathrm{H} 3$. The control by formalization construct includes two classic indicating variables, which are reporting to HQs $(1=0.71$, sign. $=0.00)$ and subsidiaries are subject to strong formal control by HQs $(1=0.62$, sign. $=0.07)$. Large MNCs with important sales in the Asia-Pacific region, when setting up RHQs or other regional management centers, reduce the level of formal control they exert over their subsidiaries in that region. At the opposite smaller MNCs without RHQs or management centers in the Asia-Pacific region, mainly base control on strong formalization of their activities and subsidiaries in the region.

The coefficient of the structural path leading from Regional structures development to Control by expatriation takes a positive value of 0.32 (sign. $=0.00$ ), which invalidates H4. French MNCs, when regionalizing their management and control functions at RHQs in the Asia-Pacific, do not reduce the level of expatriation to this region. The loadings of the indicating variables of the expatriation dimension provide further insight. As both the number of expatriates $(1=0.62$, sign. $=0.01)$ and localization of management positions $(1=0.87$, sign. $=$ 0.00) show strong positive loadings, large MNCs, which set up RHQs and other regional management centers in the Asia Pacific region still increase the number of expatriates they send while localizing management positions to Asian managers.

Looking closely to the variable "number of expatriates," we observe indeed that large MNCs with RHQs in the Asia-Pacific region maintain a greater mean number of expatriates than MNCs without RHQs (15.7 versus 8.7). However, when this absolute number of expatriates is divided by the number of subsidiaries or by the number of countries where the MNCs have activities in the Asia-Pacific region, the difference between large and small MNCs does not appear to be significant. All French MNCs in the region, with or without RHQs, maintain expatriates there. Expatriates continue to have a central role in managing the subsidiaries, particularly in exerting control, implementing corporate culture, coordinating activities and interacting with managers at HQs. When comparing the level of localization of management positions, large MNCs with RHQs employ more local managers and engineers to whom they transfer more key responsibilities compared to smaller MNCs without RHQs. This ongoing localization of management also explains the significant difference $(t=2.54$, sign. $=0.01)$ between MNCs with and without RHQs in their efforts to train local employees.

\section{Discussion}

This study investigates the following research question: how are control dimensions rearticulated at RHQs to coordinate and exert control over subsidiaries? In other words, how do HQs transfer control and coordination to RHQs? The results of our investigation show that:

- French MNCs, when creating RHQs in the Asia-Pacific region, do not reduce the level of centralized decision-making at the corporate HQs ( $H 1 a$ invalidated).

- French MNCs, when creating RHQs in the Asia-Pacific region, re-centralize decisionmaking at the regional level( $H 1 b$ validated).

- Developing regional management structures in the Asia-Pacific region increases control by socialization (H2). RHQs become places where important regional decisions are taken, where international managers meet informally and where local employees are trained.

- French MNCs, when setting up RHQs in the Asia-Pacific region, reduce the level of formal control of their subsidiaries in that region $(H 3)$. On the contrary, French MNCs without RHQs rely more on formal control, especially through strong reporting to HQs.

- French MNCs, when setting up RHQs in the Asia-Pacific region, do not reduce the level of expatriation to the region ( $H 4$ invalidated). Moreover, French MNCs with RHQs transfer regional responsibilities to local managers and technicians. 
When MNCs become larger and too complex to be managed centrally, they set up RHQs. French MNCs transfer coordination and control functions to those RHQs, without releasing central decision-making at the HQs. Using Perlmutter and Heenan's (1974) concept of regio- centrism, we propose calling this "regio-centralization".

Referring to Lasserre (1996), Ambos (2016, p. 30) state that "a pioneering aspect of his work lies in the claim that RHQs change their parenting profiles over time [.. .] because of the maturing of regional operations." Thus:

[.. .] it might be interesting to further build on Lasserre's seminal work and apply the idea of evolving parenting functions not only on the regional, but also on the corporate level (Ambos, 2016, p. 37).

This is consistent with the assertion by Kostova et al. (2016, p. 180) that "many MNCs had begun developing regional centers of coordination and control to better seize regional opportunities, and leverage local resources and knowledge throughout the entire organization".

From a dynamic perspective, regio-centralization can be viewed as a balance between the control functions transferred to RHQs and the remaining decision-making power at HQs. By studying dimensions of control, we observe that this process is the result of constant adjustment between RHQs and HQs.

\section{Process of regio-centralization}

Regarding the rearticulating of control dimensions at RHQs to coordinate and exert control over subsidiaries, our research provides further interesting findings.

- Centralization: Large MNCs simultaneously continue to centralize decision-making at HQs while granting more decision autonomy to RHQs, under the HQs' supervision; small MNCs, without RHQs, still centralize control and coordination at HQs.

- Socialization: RHQs become socialization hubs where international managers (expatriates, short-term assignees, HQs visitors and local managers) meet; it is an important form of informal coordination. Moreover, RHQs develop training of local staff.

- Formalization: Large MNCs emphasize less formalization but develop informal control at RHQs; small MNCs without RHQs hubs still formalize coordination and control of subsidiaries in the Asia-Pacific region.

- Expatriation: MNCs mobilize all categories of international managers, including expatriates, short-term assignees and HQs visitors; at the same time, they localize management and transfer management and engineering positions to local employees. When MNCs develop massively in a given area and in strategically sensitive markets, expatriates are still regarded as a crucial developmental resource (Schaaper et al., 2013).

Our results reveal the means that RHQs and HQs use to achieve regio-centralization. As noted by Conroy et al. (2017), increased delegation of decision-making responsibility from corporate HQs to subsidiaries and intermediary units within the MNC has resulted in an increased focus on interactions among units (Geppert et al., 2016; Morgan and Kristensen, 2006). This regio-centralization is (co-)constructed by acting on different dimensions of control (centralization, socialization, formalization and expatriation). A constant mutual alignment of control and coordination mechanisms takes place across the various control dimensions:

- Socialization plays a major role, in line with what Conroy et al. (2017) call "micropolitical strategies of alignment." The RHQs are aligning with central HQs through increasing exchange. Corporate visits (HQs visits and short-term assignments) provide valuable informal platforms for exchanging knowledge and information. This corroborates the empirical findings of Nell et al. (2011, p. 98) that RHQs managers attempt to "increase their centrality in the MNC's network." The loadings that we find for HQs visits, short-term assignments and informal control clearly denote the importance of informal control mechanisms. Informal control, including the development of personal networks and the training role of RHQs, is a key mechanism of regio-centralization. This is in line with previous research (Ambos et al., 2018; Decreton et al., 2019; Brenner and Ambos, 2013).

- Formalization may be lessened thanks to the regio-centralization process, especially among large MNCs. The validation of $H 3$ on reduced control by formalization indicates that less formal control at HQs is compensated for by more informal control 
at RHQs, a shift apparently secured through strengthened reporting practices.

- Regarding expatriation, the invalidation of $H 4$ shows that expatriates still have a key role in regional structures and subsidiaries' management. With regard to regiocentralization, it resonates with the socialization dimension. The main roles of expatriates are exerting control, implementing corporate culture overseas, coordinating activities and interacting with managers atHQs.

Overall, as the structural path coefficients show, RHQs development positively affects centralization and socialization and to a lesser extent expatriation. On the contrary, it negatively affects formalization in the relationships between subsidiaries and HQs.

Our statements on regio-centralization also resonate with Verbeke and Asmussen's (2016) findings about regional strategy development by MNCs. These authors emphasize regional strategies as relevant in most industries where regional differences remain, leading to a reduction in costs due to regional economies of scales and responsiveness at regional levels. However, developing regional strategies requires capabilities to:

- Identify regional opportunities for the firm.

- Transfer non-location bound firm specific advantages (FSAs) from the home region to the host.

- Nurture region-bound FSAs when possible by organizing activities in various parts of the host region, both internally and externally.

To do so, RHQs should be staffed sufficiently, with both expatriates (H4 invalidated) and local staff, who exhibit an ability to transfer and nurture knowledge (socialization, H2).

Overall, we see that the development of regional structures has a differentiated impact on the control dimensions of socialization, formalization, centralization and expatriation. This can probably be interpreted by the fact that centralization and formalization rely very largely on rules and procedures that can be administered from HQs, whereas socialization relies largely on interpersonal contacts and networks that are probably more effective at a regional level (Decreton et al., 2019).

\section{Conclusion}

With a sample of 86 French MNCs, we investigate the bridging role of RHQs in terms of coordination and control of activities in the Asia Pacific region. Our structural equation model allows us to test a set of hypotheses.

We find especially that large MNCs, on a worldwide scale, with important sales in the

Asia-Pacific region, set up in this region one or more regional management centers to which they transfer managerial functions. Our structural equation modeling reveals that these large MNCs grant regional control and decisionmaking authority to their RHQs while not giving up centralized supervision, a feature that leads us to suggest the use of the expression regio-centralization. Furthermore, socialization is highly developed at RHQs, to some extent at the expense of formalization among the largest MNCs. RHQs become socialization hubs, where HQs managers on business visits, short-term assignees, expatriates and other Asia- Pacific managers meet, exchange information informally and develop social networks. Expatriation remains a crucial tool for controlling and developing activities in the region. However, large MNCs especially are in a process of transferring regional management responsibilities to local managers. Smaller MNCs, without RHQs in the Asia-Pacific region, base their control and coordination on the formalization of the HQs-subsidiary relationships, especially through strong reporting, in combination with centralized decision-making at the domestic HQs.

This research is entirely based on MNCs from one specific country, France. Investigating cases from only one country helps neutralize some institutional variables, and the French case is not much studied in the international management literature. Furthermore, our research focuses on the Asia-Pacific as a host region, which is a highly dynamic area. Coordination and control in less dynamic regions of the world may reveal different characteristics, which would be useful to investigate.

This study contributes to the ongoing conversation about regional strategy development by MNCs. Not only are RHQs key components for the coordination and control of activities throughout the host region, they also have a 
strategy formation role (Verbeke and Asmussen, 2016). The expression "regio-centralization" emphasizes the notion that when they create RHQs, MNCs do not give up centralized decision-making or control. Instead, they reorganize these activities by involving RHQs members. In this way, MNCs can resolve the problems that come with increasing size and complexity, as well as leverage resources and capabilities that they nurture at the RHQs level. Ultimately then, RHQs appear closely involved in coordination and control activities, on the one hand, and in strategic decision- making, on the other hand. 
Notes

1. Appendix 2 gives a detailed overview of the operationalization of the indicating variables of the structural model.

2. We programmed the SmartPLS 3 software with the following options, namely, Z-standardization, path-weighting scheme, a stop criterion of $10^{-7}$ and bootstrapping with 1,000 subsamples.

3. The three omitted indicating variables were level of shared values, $1=0.29$, sign. $=0.36$ (socialization); number of written formal documents and procedures, $1=0.35$, sign. $=0.34$, (formalization) and number of key functions occupied by expatriates, $1=0.41$, sign. $=0.24$ (expatriation)

4. Appendix 1 reproduces the graph of the full structural equation model, including the loadings and significance levels of the 12 remaining significant indicating variables.

5. To be specific, an outer loading between 0.4 and 0.7 is acceptable and retained if it is associated with a reflective construct for which the AVE $>0.50$ and CR $>0.60$ (Hair, 2016, p. 103).

6. The collinearity assessment (Hair, 2016, p. 170) reveals variance inflation factors between 1.24 and 3.22 and tolerance levels between 0.31 and 0.81 .

\section{References}

Alfoldi, E.A., Clegg, J. and Mc Gaughey, S. (2012), "Coordination at the edge of the empire: the delegation of headquarters functions through regional management mandates", Journal of International Management, Vol. 18 No. 3, pp. 276-292.

Amann, B., Jaussaud, J. and Schaaper, J. (2014), "Clusters and regional management structures by western MNCs in Asia: overcoming the distance challenge”, Management International Review, Vol. 54 No. 6, pp. 879-906.

Amann, B., Jaussaud, J. and Schaaper, J. (2017), "Control in subsidiary networks in Asia: toward an extension of the centralisation-formalisation-socialisation model", Management International, Vol. 21 No. 4, pp. 89-108.

Ambos, B. (2016), “Comments on 'regional headquarters: the spearhead for Asia pacific markets', philippe lasserre”, Long Range Planning, Vol. 29 No. 1, pp. 41-43.

Ambos, B. and Schlegelmich, B.D. (2007), "Innovation and control in the multinational firm: comparison of political and contingency approaches", Strategic Management Journal, Vol. 28 No. 5, pp. 473-486.

Ambos, B. and Schlegelmich, B.D. (2010), The New Role of Regional Management, Palgrave Macmillan, New York, NY.

Ambos, B., Kunisch, S., Leicht-Deobald, U. and Steinberg, A.S. (2018), "Unravelling agency relations inside the MNC: the roles of socialization, goal conflicts and second principals in headquarters- subsidiary relationships", Journal of World Business, Vol. 54 No. 2, pp. 67-81.

Ando, N., Rhee, D.K. and Park, N.K. (2008), "Parent country nationals or local nationals for executive positions in foreign affiliates: an empirical study of Japanese affiliates in Korea", Asia Pacific Journal of Management, Vol. 25 No. 1, pp. 113-135.

Arregle, J.L., Miller, T.L., Hitt, M.A. and Beamish, P.W. (2016), “How does regional institutional complexity affect MNE internationalization?”, Journal of International Business Studies, Vol. 47 No. 6, pp. 697-722.

Arregle, J.L., Miller, T.L., Hitt, M.A. and Beamish, P.W. (2018), “The role of MNEs' internationalization patterns in their regional integration of FDI locations", Journal of World Business, Vol. 53 No. 6, pp. 896-910.

Bartlett, C.A. and Ghoshal, S. (1989), Managing across Borders: The Transnational Solution, Harvard Business School Press, Boston, Mass. 
Belderbos, R., Du, H.S. and Goerzen, A. (2017), "Global cities, connectivity, and the location choice of MNC regional headquarters: global cities and regional headquarters location”, Journal of Management Studies, Vol. 54 No. 8, pp. 1271-1302.

Brenner, B. and Ambos, B. (2013), "A question of legitimacy? A dynamic perspective on multinational firm control”, Organization Science, Vol. 24 No. 3, pp. 773-795.

Chakravarty, D., Hsieh, Y.Y., Schotter, A.P.J. and Beamish, P.W. (2017), "Multinational enterprise regional management centres: characteristics and performance", Journal of World Business, Vol. 52 No. 2, pp. 296-311.

Conroy, K.M., Collings, D.G. and Clancy, J. (2017), "Regional headquarters' dual agency role: micro- political strategies of alignment and self-interest”, British Journal of Management, Vol. 28 No. 3, pp. 390-406.

Decreton, B., Nell, P.C. and Stea, D. (2019), "Headquarters involvement, socialization and entrepreneurial behaviors in MNC subsidiaries", Long Range Planning, Vol. 52 No. 4.

Diamantopoulos, A., Sarstedt, M., Fuchs, C., Wilczynski, P. and Kaiser, S. (2012), "Guidelines for choosing between multi-item and single-item scales for construct measurement: a predictive validity perspective", Journal of the Academy of Marketing Science, Vol. 40 No. 3, pp. 434-449.

Edström, A. and Galbraith, J.R. (1997), "Transfer of managers as a coordination and control strategy in multinational organizations", Administrative Science Quarterly, Vol. 22, pp. 48-263.

Enright, M.J. (2005), “The role of regional management centers”, Management International Review, Vol. 45 No. 1, pp. 83-102.

Geppert, M., Becker-Ritterspach, F. and Mudambi, R. (2016), "Politics and power in multinational companies: Integrating the international business and organization studies perspectives", Organization Studies, Vol. 37 No. 9, pp. 1209-1225.

Geringer, J.M. and Hebert, L. (1989), "Control and performance of international joint ventures”, Journal of International Business Studies, Vol. 20 No. 2, pp. 235 254.

Ghoshal, S. and Nohria, N. (1989), "Internal differentiation within multinational corporations", Strategic Management Journal, Vol. 10 No. 4, pp. $323-337$.

Hair, J.F. (Ed.). (2016), A Primer on Partial Least Squares Structural Equation Modeling (PLS-SEM), Second edition, Sage, Los Angeles.

Harzing, A.W. and Noorderhaven, N. (2006), "Geographical distance and the role and management of subsidiaries: the case of subsidiaries down-under", Asia Pacific Journal of Management, Vol. 23 No. 2, pp. 167-185.

Hoenen, A., Nell, P. and Ambos, B. (2013), "MNE entrepreneurial capabilities at intermediate levels: the roles of external embeddedness and heterogeneous environments", Long Range Planning, Vol. 47 Nos 1/2, pp. 76-86.

Kim, K., Park, J.H. and Prescott, J.E. (2003), "The global integration of business functions: a study of multinational businesses in integrated global industries", Journal of International Business Studies, Vol. 34 No. 4, pp. 327-344.

Kostova, T., Marano, V. and Tallman, S. (2016), "Headquarters subsidiary relationships in MNCs: fifty years of evolving research",Journal of World Business, Vol. 51 No. 1, pp. 176-184.

Kumar, S. and Seth, A. (1998), "The design of coordination and control mechanisms for managing joint venture - parent relationships", Strategic Management Journal, Vol. 19 No. 6, pp. 579-599.

Lasserre, P. (1996), "Regional headquarters: the spearhead for Asia pacific markets", Long Range Planning, Vol. 29 No. 1, pp. 30-37.

Lehrer, M. and Asakawa, K. (1999), "Unbundling European operations: regional management and corporate flexibility in American and Japanese MNCs", Journal of World Business, Vol. 34 No. 3, pp. 267-286.

corporate decisions in networked MNCs?", Journal of International Management, Vol. 18 No. 3, pp. 293-301. 
Mayerhofer, H., Hartmann, L.C. and Hebert, A. (2004), "Career management issues for flexpatriate international staff", Thunderbird International Business Review, Vol. 46 No. 6, pp. 647-666.

Morgan, G. and Kristensen, P.H. (2006), “The contested space of multinationals: varieties of institutionalism, varieties of capitalism”, Human Relations, Vol. 59 No. 11, pp. 1467-1490.

Mori, T. (2002), "The role and function of European regional headquarters in Japanese MNCs", Working paper No. 141, Hirosaki University, Japan.

Nell,P.C., Ambos, B. and Schlegelmilch, B.B. (2011), "The benefits of hierarchy? Exploring the effects of regional headquarters in multinational corporations", in Asmussen, C.G., Pedersen, T., Devinney, T.M. and Tihanyi, L. (Eds), Dynamics of Globalization: Location-Specific Advantages or Liabilities of Foreignness?, Emerald Group Publishing, Bingley pp. 85-106.

Nell, P.C., Kappen, P. and Laamanen, T. (2017), "Reconceptualising hierarchies: the disaggregation and dispersion of headquarters in multinational corporations", Journal of Management Studies, Vol. 54 No. 8, pp. 1121-1143.

Nobel, R. and Birkinshaw, J. (1998), "Innovation in multinational corporations: control and communication patterns in international R\&D operations", Strategic Management Journal, Vol. 19 No. 5, pp. 479-498.

Nohria, N. and Ghoshal, S. (1994), "Differentiated fit and shared values: alternatives for managing headquarters-subsidiary relations", Strategic Management Journal, Vol. 15 No. 6,pp.491-502.

Oh, C.H. and Rugman, A. (2014), "The dynamics of regional and global multinationals, 1999-2008", Multinational Business Review, Vol. 22 No. 2, pp. 108-117.

Perlmutter, H.V. and Heenan, D.A. (1974), “How multinational should your top managers be?”, Harvard Business Review, Vol. 52 No. 6, pp. 121-132.

Piekkari, R., Nell, P.C. and Ghauri, P.N. (2010), "Regional management as a system: a longitudinal case study”, Management International Review, Vol. 50 No. 4, pp. 513-532.

Poon, J.P. and Thompson, E.R. (2003), “Developmental and quiescent subsidiaries in the Asia pacific: evidence from Hong Kong, Singapore, Shanghai and Sydney”, Economic Geography, Vol. 79 No. 2, pp. 195-214.

Ral-Trebacz, A., Eckert, S. and Dittfeld, M. (2018), "The value of internationalization: disentangling the interrelationship between regionalization strategies, firmspecific assets related to marketing and performance", Multinational Business Review, Vol. 26 No. 1, pp. 71-90.

Rugman, A.M. and Brain, C. (2003), "Multinational enterprises are regional, not global”, Multinational Business Review, Vol. 11 No. 1, pp. 3-12.

Rugman, A.M. and Verbeke, A. (2008), "A new perspective on the regional and global strategies of multinational services firms", Management International Review, Vol. 48 No. 4, pp. 397-411.

Schaan, J.L. (1988), "How to control a joint venture even as a minority partner”, Journal of General Management, Vol. 14 No. 1, pp. 4-16.

Schaaper, J., Amann, B., Jaussaud, J., Nakamura, H. and Mizoguchi, S. (2013), "Human resource management in Asian subsidiaries: comparison of French and Japanese MNCs", The International Journal of Human Resource Management, Vol. 24 No. 7, pp. 1454-1470.

Schotter, A.P.J., Stallkamp, M. and Pinkham, B.C. (2017), "MNE headquarters disaggregation: the formation antecedents of regional management centers: regional MNE headquarters disaggregation”, Journal of Management Studies, Vol. 54 No. 8, pp. 1144-1169.

Schütte, H. and Selmer, J. (1997), "Strategy and organisation: challenges for European MNCs in Asia”, European Management Journal, Vol. 15 No. 4 , pp. 436-445.

Selmer, J. (2003), "Staff localization and organizational characteristics: western business operations in China”, Asia Pacific Business Review, Vol. 10 No. 1 , pp. 43-57.

Tahvanainen, M., Welch, D. and Worm, V. (2005), "Implications of short-term internationalassignments", European Management Journal, Vol. 23 No. 6, pp. 
663-673.

Tung, R.L. (1981), "Selection and training of personnel for overseas assignments", Columbia Journal of World Business, Vol. 16 No. 1 , pp. 68-78.

Verbeke, A. and Asmussen, C.G. (2016), "Global, local, or regional? The locus of MNE strategies”, Journal of Management Studies, Vol. 53 No. 6, pp. 1051-1075.

Willis, R. and Chiasson, M. (2007), "Do the ends justify the means? A Gramscian critique of the processes of consent during an ERP implementation", Information Technology and People, Vol. 20 No. 3, pp. 212-234.

Wong, C. and Law, K.S. (1999), "Managing localization of human resources in the PRC: a practical model", Journal of World Business, Vol. 34 No. 1, pp. 2640.

Yeung, H.W., Poon, J. and Perry, M. (2001), "Towards a regional strategy: the role of regional headquarters of foreign firms in Singapore", Urban Studies, Vol. 38 No. 1, pp. 157-158.

\section{Further reading}

Asmussen, C.G., Nielsen, B.B., Osegowitsch, T. and Sammartino, A. (2015), “The dynamics of regional and global expansion", Multinational Business Review, Vol. 23 No. 4, pp. 306-327.

Egelhoff, W.G. (1980), "Structure and strategy in multinational corporations: a re-examination of the stopford and wells model", Strategic Management Journal, Vol. 9 No. 1, pp. 1-14.

Egelhoff, W.G. (1982), "Strategy and structure in multinational corporations: an information processing approach", Administrative Science Quarterly, Vol. 27 No. 3,pp. 435-458. 


\section{Appendix 1}

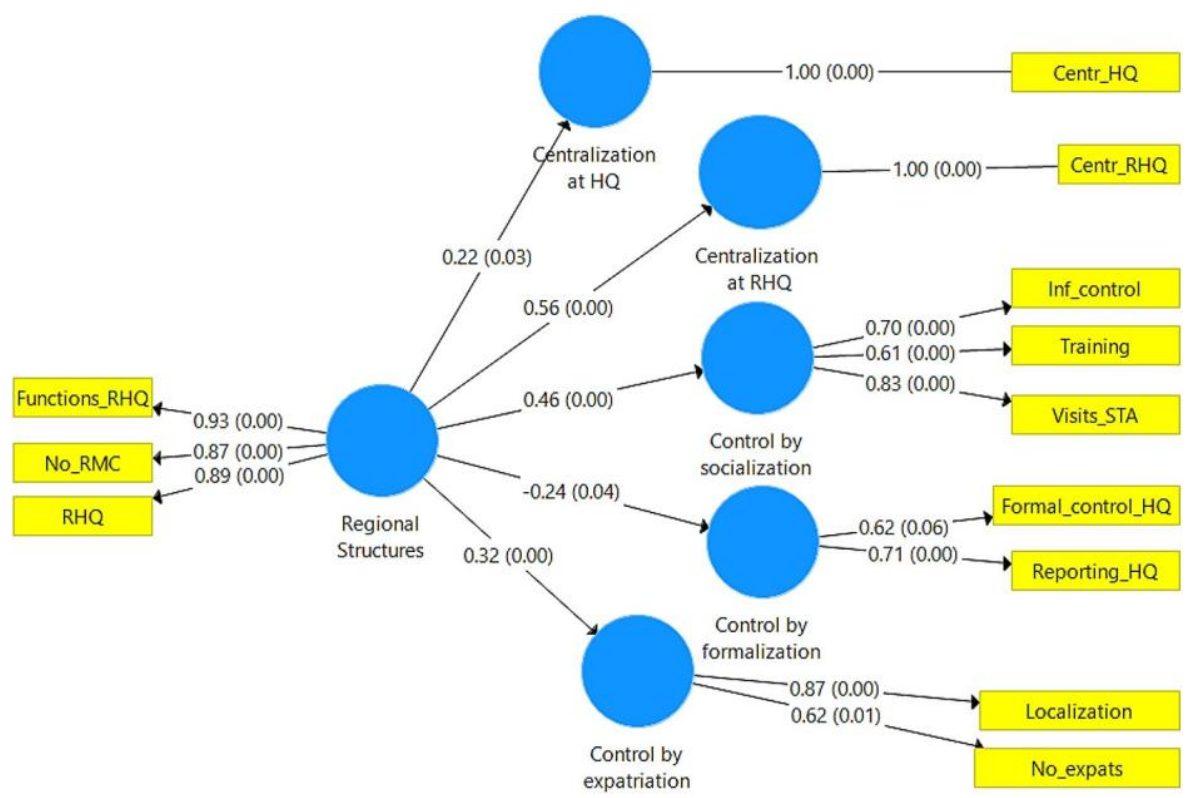

Figure A1. The full structural equation model, with path coefficients, loadings and significance levels, as produced by SmartPLS 3.0 


\section{Appendix 2}

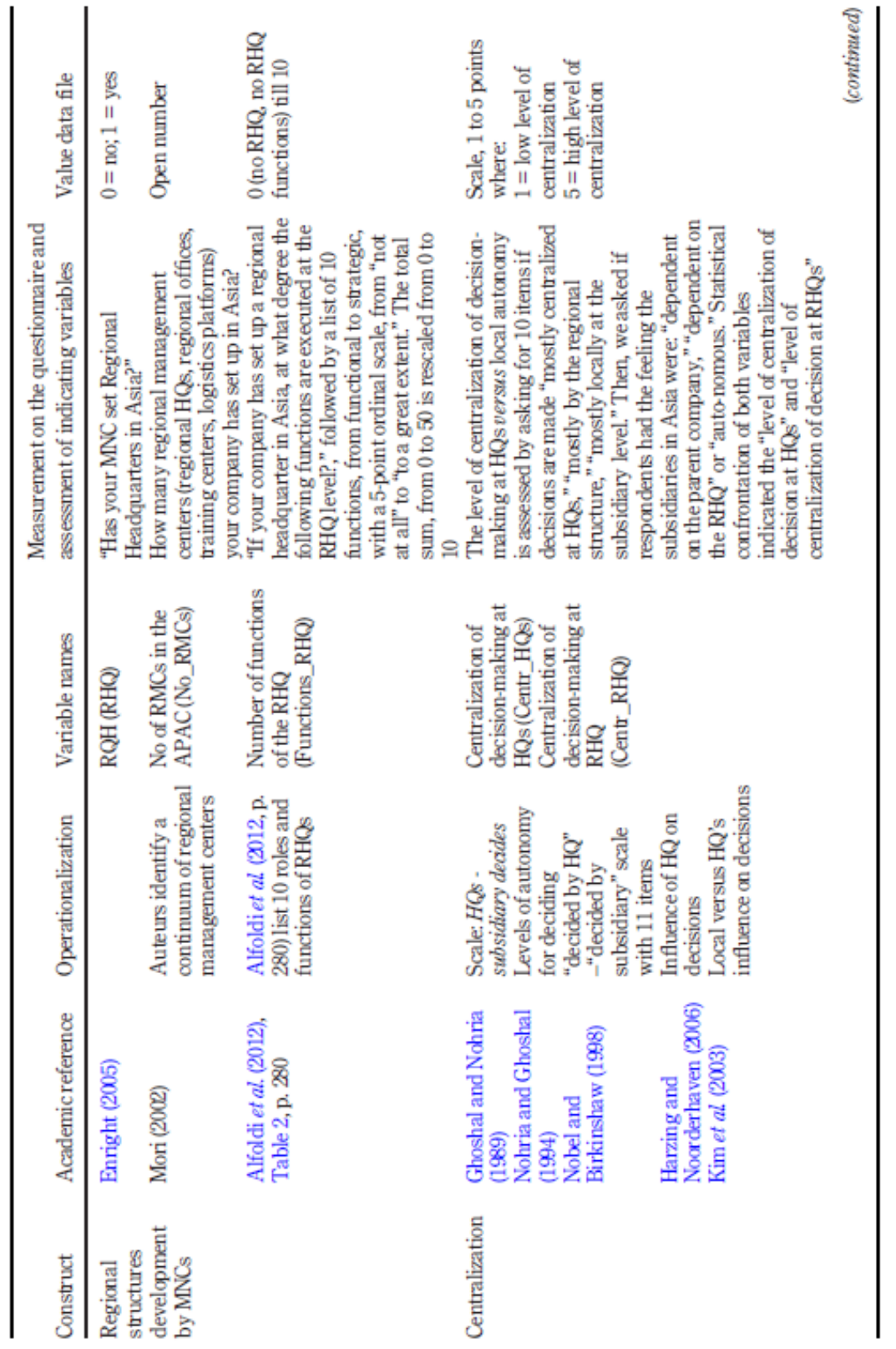

Table A1.Detailed overview of the operationalization of the indicating variables of the structural model 


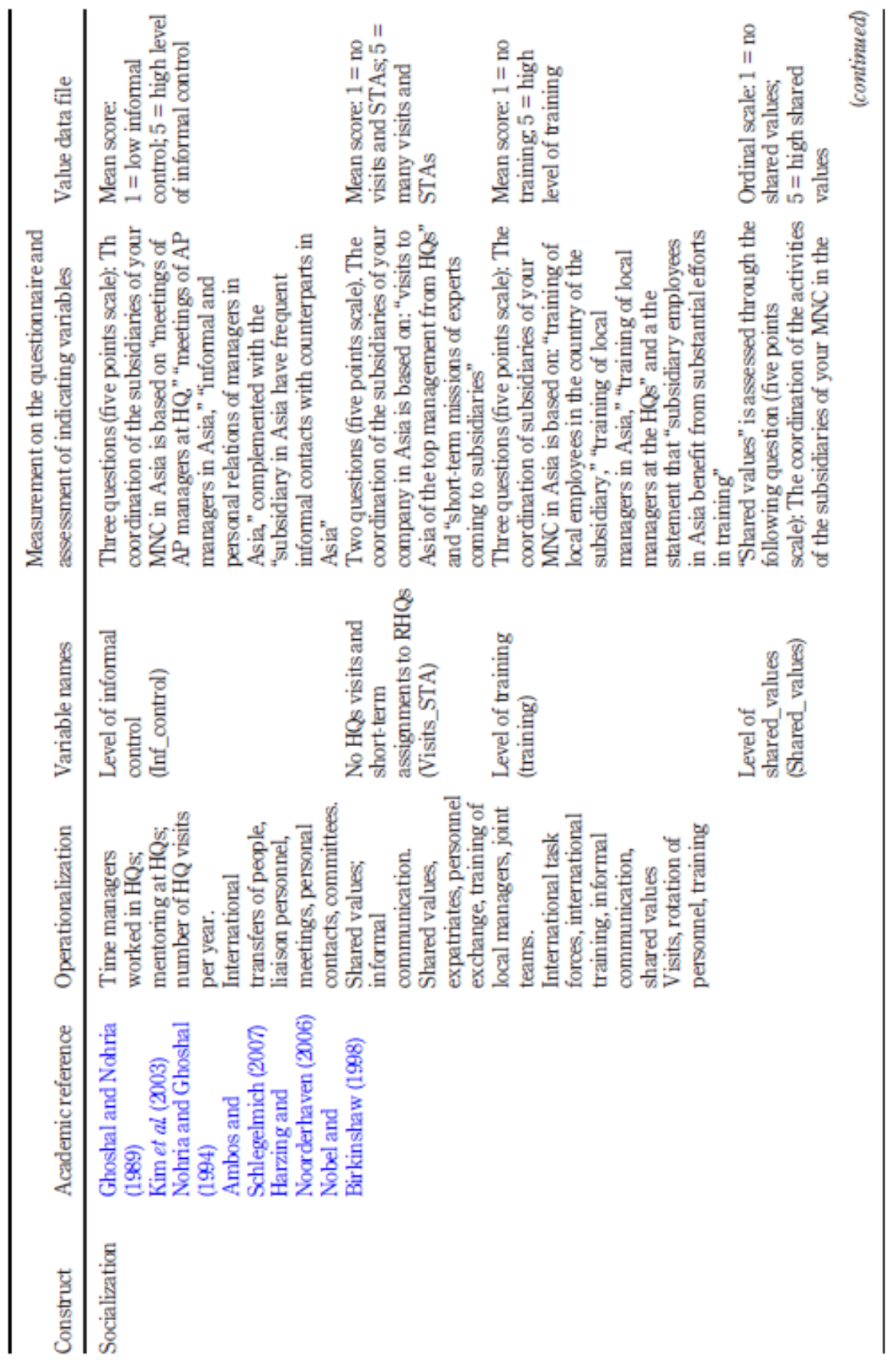

Table A1. 


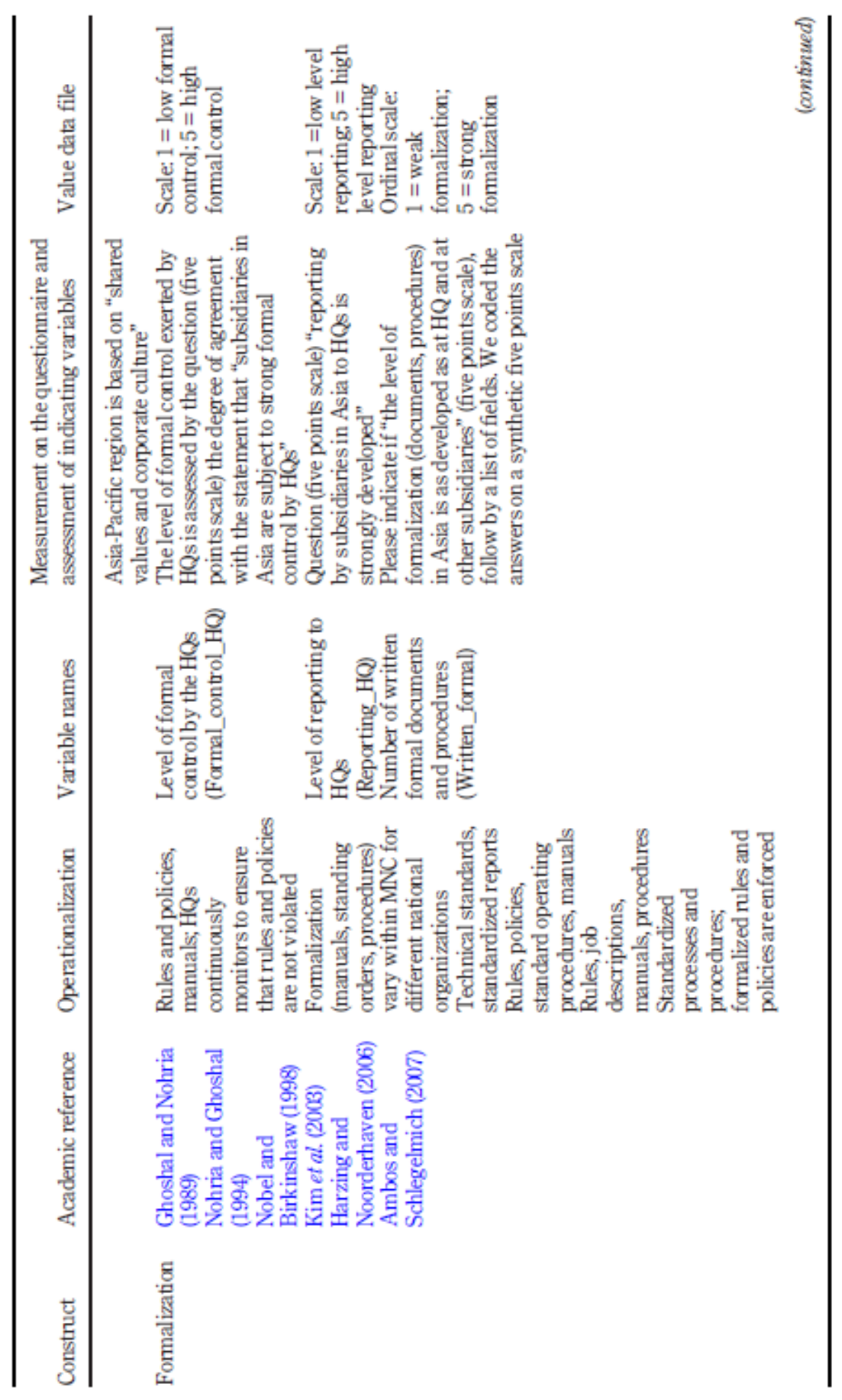

Table A1. 


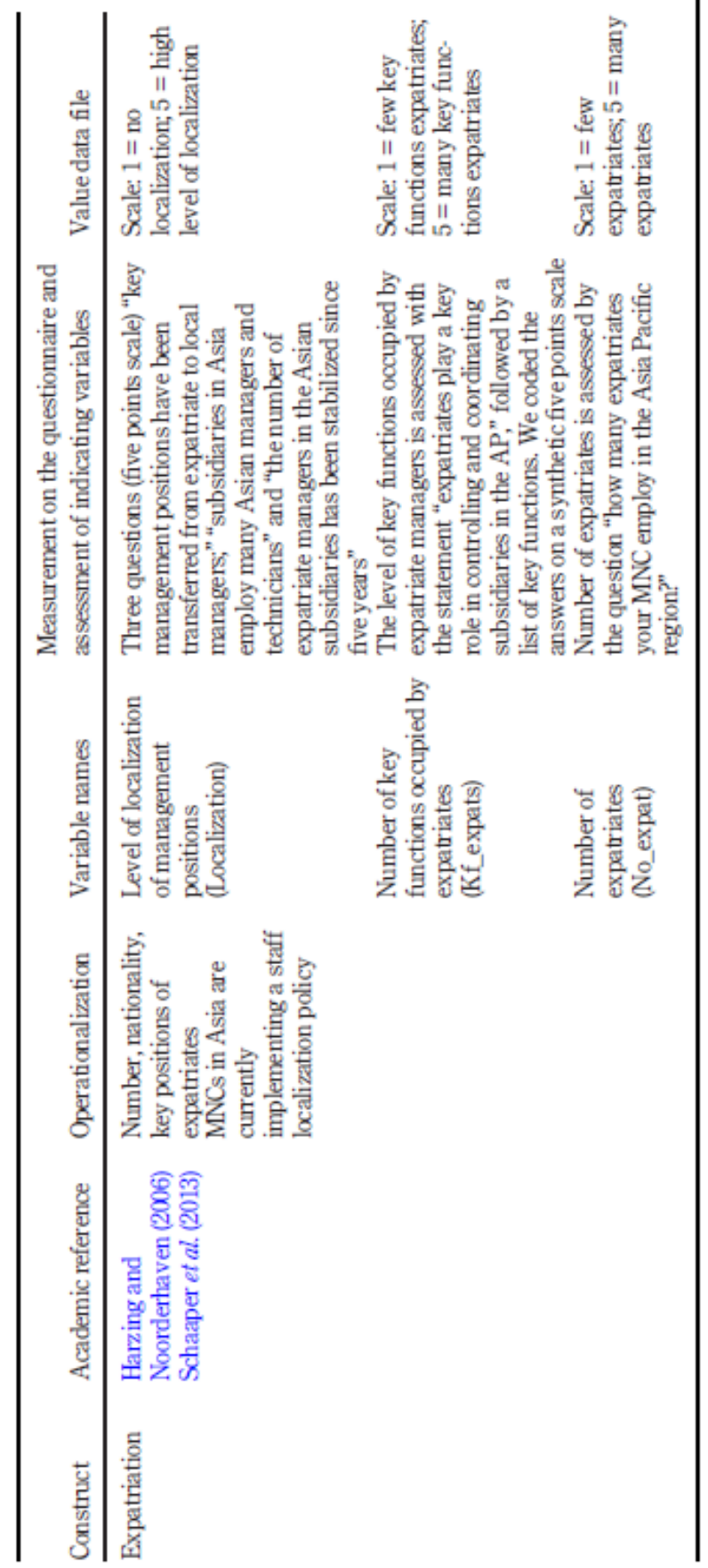

Table A1 


\section{Appendix 3}

\begin{tabular}{|c|c|c|c|c|c|c|c|c|c|c|c|c|}
\hline Variables & Mean & SD & 1 & 2 & 3 & 4 & 5 & 6 & 7 & 8 & 9 & 1011 \\
\hline 1. RHQ & 0.67 & 0.47 & - & & & & & & & & & \\
\hline $\begin{array}{l}\text { 2. Important } \\
\text { functions RHQ } \\
\text { 3. Number of RMCs }\end{array}$ & 3.10 & 2.52 & $0.83^{* *}$ & - & & & & & & & & \\
\hline in APAC & 1.09 & 1.18 & $0.62^{* *}$ & $0.71^{* *}$ & - & & & & & & & \\
\hline $\begin{array}{l}\text { 4. Centralization } \\
\text { decision at } \mathrm{HQ} \text { s } \\
\text { 5. Centralization }\end{array}$ & 2.38 & 1.19 & $0.27^{*}$ & 0.15 & 0.16 & - & & & & & & \\
\hline $\begin{array}{l}\text { RHQ in APAC } \\
\text { 6. Short-term }\end{array}$ & 2.46 & 1.19 & $0.41^{* *}$ & $* 0.56^{* *} 0$ & $0.55^{* *}$ & 0.06 & - & & & & & \\
\hline assignments APAC & 3.20 & 1.02 & $0.41^{\text {*** }}$ & $0.41^{* * *} 0$ & $0.48^{* *}$ & 0.15 & $0.30^{*}$ & - & & & & \\
\hline $\begin{array}{l}\text { 7. Informal control } \\
\text { 8. Level of training }\end{array}$ & 3.44 & 0.85 & $0.21^{*}$ & $0.23^{*}$ & $0.25^{*}$ & 0.18 & -0.08 & $0.42^{* *}$ & - & & & \\
\hline APAC & 2.98 & 1.17 & $0.30^{*}$ & $0.26^{*}$ & $0.24^{*}$ & $0.37^{\text {** }}$ & 0.11 & 0.18 & $0.41^{\text {** }}$ & * & & \\
\hline $\begin{array}{l}\text { 9. Level reporting } \\
\text { 10. Level control by }\end{array}$ & 3.52 & 1.18 & $-0.34^{* * *}$ & -0.17 & -0.17 & 0.09 & -0.20 & -0.11 & $0.22^{*}$ & 0.16 & - & \\
\hline $\begin{array}{l}\text { HQs } \\
\text { 11. Number }\end{array}$ & 3.92 & $1.01-$ & -0.11 & -0.07 & -0.12 & $0.24^{*}$ & -0.14 & -0.01 & 0.07 & 0.09 & $0.35^{* *}$ & - \\
\hline $\begin{array}{l}\text { expatriates in } \\
\text { APAC }\end{array}$ & 14.12 & 23.3 & 0.12 & 0.20 & 0.18 & -0.20 & 0.02 & -0.03 & -0.10 & 0.08 & -0.230 & $0.26^{*}-$ \\
\hline 12. Localization & 2.56 & 0.96 & $0.28^{*}$ & $0.249^{*}$ & $0.27^{*}$ & $0.24^{*}$ & 0.10 & $0.52^{* *}$ & $0.42^{* *} 0$ & $39^{* * * *}($ & 0.040 .08 & 80.15 \\
\hline Notes: ${ }^{*} p<0.05 ;{ }^{* *}$ & $p<0$ & & & & & & & & & & & \\
\hline
\end{tabular}

Table A2. Correlation matrix between 12 original indicating variables

\section{Corresponding author}

Johannes Schaaper can be contacted at: jschaaper@u-bordeaux.fr 